seyde monastery, there haithe beyne payde, as dothe apere more particularly by the bouke we send yower lordshippe, cxlix ${ }^{11}$; and forasmoche as thabbott haithe nott receyryd of hus in redy money butt $\mathrm{xx}^{\mathrm{li}}$, he haithe requyerde me to desyer yower lordshippe to be so good lorde unto hym he may have $\mathrm{xx}^{\mathrm{li}}$. or twentie markes more. The churche and house remenythe as yet undefacede; and in the chirche be meny thynges to be maide sale of, for the wiche yt may plese yower lordshippe to lett me knawe yower pleysure, as well for the farther sale to be made as for the defasinge of the chirche and other superfluus byldinges wiche be abowte the monastery. A hundrithe markes yerly will not susteyne the charges in reparyng this house, yf all byldinges be lett stande, as yower lordshippe shall knowe more hereafter. Thus I pray Jhesus longe to preserve yow in helthe withe muche honore. Wrytten at the late monastery of Leycester, the xxix th day of Auguste, by yower lordshipes most bownden servantt,

Frauncis Cave.

The following letter relates to a similar subject to that spoken of in the preceding, the demolition of the monasteries of Jervaux and Bridlington. Bridlington priory (already mentioned) came into the king's hand by the attainder of the prior, who was active in the rebellion of 1536 .

\title{
LXXXII.
}

RICHARD BELLASYS TO CROMWELL.

[From MS. Cotton. Cleop. E. Iv. fol. 241.]

Pleashithe your good lordship to be advertysed, I have taken down all the leade of Jarvaxe, and maid it in pecys of half foders, whyche leade amowntythe to the nombre of eghten skore and fyve foders, wythe thryttye and ffowre foders and a half that were there byfore; and the said leade can not be conveit nor caryed unto the next sombre, for the ways in that cowntre are so foule 
and deape that no caryage can passe in wyntre. And as concerninge the rasing and takyn down the howse, if it be your lordships pleasour, I ame myndet to let it staunde to the sprynge of the yere, by reason the days ar now so short, it wolde be doble charges to doo it now. And as concerninge the sellyng of the belles, I can not sell them above $\mathrm{xv}^{\mathrm{s}}$. the howndrethe, wherin I wolde gladly knowe your lordships pleasour whether I shuld sell them after that pryce, or send them up to London; and if they be sent up, surely the caryage wolbe costly frome that place to the water. And as for Byrdlington, I have doyn nothing there as yet, but sparythe it to Marche next, bycause the days now are so short; and frome suche tyme as I begyn, I trust shortlye to dyspache it, after suche fashon, that when all is fynished, I trust your lordship shall think that I have ben no evyll howsband in all suche thinges as your lordship haithe appoynted me to doo. And thus the Holye Gost ever preserve your lordship in honour. At Yorke, this xiijth daye of Novembre, by your most bounden beademan,

\section{Richard BeLLYCys.}

The following letter gives a brief account of the dissolution of a number of monastic houses of the north of England.

The Benedictine abbey of Burton-on-Trent, in Staffordshire, was of Saxon origin, having been founded about the year 1002 by Wulfric Spott. In ancient times it was often called Modwennestow, because the relics of St. Modwen were enshrined there. William Edys was the last abbot: the date of the surrender given in the last edition of the Monasticon, 1539, must be wrong, and appears to have originated from a mistake of the date of the present letter.

The alien priory of Pontefract in Yorkshire was founded by Robert de Lacy in the reign of William Rufus, and was made dependent on the foreign house of La Charite sur Loire, whence the first monks of the English house were brought. The last prior was James Thwayts.

The Cistercian abbey of Fountains, the magnificent ruins of which still excite the admiration of visitors, was founded in $\mathbf{1 1 3 2}$ by a colony of monks from St. Mary's at York. The last abbot was Marmaduke Brodelay, or Bradley, suffragan bishop of Hull.

St. Mary's abbey at York bas been mentioned on a former page.

Nun-Appleton was a nunnery near Tadcaster, in the West Riding of Yorkshire, founded by Alice de St. Quintin in the latter part of the reign of Stephen. The last prioress was Anne Langton. 
The rich mitred-abbey of Selby in Yorkshire, was founded by William the Conqueror in 1069. The last abbot was Robert Selby or Rogers. The fine abbey church is still entire.

The hospital of St. Leonard at York is said to have been first endowed by king Athelstan, and to have been refounded by William Rufus.

It may be observed that the dates of the surrender of nearly all these houses appear to he wrongly given in the Monasticon.

\section{LXXXIII.}

THE COMMISSIONERS OF THE NORTH TO CROMWELL.

[From MS. Cotton. Cleop. E. Iv. fol. 242.]

After meest humble commendacions to your good lordship, pleaseth it the same be advertiesed, that we have altered Burtonupon-Trent; and accordinge to the kinges highnes commission and instruccions we have dissolved the howses of Hampole, Sancte Oswaldes, Pountefracte, Fontaunce, Sancte Maries in Yourke, Nonappleton, and Selbye, and also altered the howse of Sancte Leonerdes in Yourke, after suche ordre and fassion as we trust shall appeir to your lordship to be to the kinges honour and contentacion. Albeit, we could natt maike dispeche in parte of the said places withoute some difficultie, as your lordship shall perceyve at our repayer to Londone, ffurther certifienge your lordship that we have takyn the shrynes in all such places as we have yett hetherto repayrede unto the kinges use; and forasmoche as we have no commission in that behalf, we beseiche youe that we may have a commission for that purpouse, beringe date of the other commissions, to shewe if neede shall requier. And thus our Lorde ever preserve your goode lordship in moche honour. At Selbie, the viijth day of Decembre.

Yours at commandement,

Waltere Hendee.

Richarde Layton.

Thomas Legh.

RYChaRd BeLasSYs.

Richard Watkyns. 